\title{
Research and practice on the cultivation of innovative and entrepreneurial talents in the applied Undergraduate Electronic Commerce Specialty
}

\author{
Teaching reform of talents cultivation for Undergraduate \\ Electronic Commerce Specialty under the era of "Internet +" \\ Bo Yang \\ Huashang College Guangdong University Of Finance \& Economics, Guangzhou zengcheng, China
}

Keywords: Applied undergraduate; Internet +; Electronic commerce; Innovation and entrepreneurship; Talent cultivation

\begin{abstract}
After put forward the call of "public entrepreneurship and mass innovation", set off a new wave of "public entrepreneurship, grassroots entrepreneurship", formed the new situation of "mass innovation, everyone innovation ". This is a new engine of China's economic growth, ushered the golden opportunity of innovation and entrepreneurship, especially, the entrepreneurial advantage of "Internet +" model is quite apparent. The college students group with most dynamic and creative is the major force of innovation and entrepreneurship, among them, the applied talents who not only understand Internet technology but also know business which trained by the electronic commerce specialty should take their own advantages to grasp the opportunity, to alleviate employment pressure. In this paper, shared some practical experience that the applied undergraduate colleges and universities should focus on how to put effort into training "Internet +" innovative and entrepreneurial talents of e-commerce specialty.
\end{abstract}

\section{The research background and significance}

"Public entrepreneurship and mass innovation" is the source of power of the economic growth in China, is the path to enrich people, and is the strategy to strengthen country, is also the major initiatives to steady growth and promote employment. At present, the innovation and entrepreneurship located in the national strategic height is unprecedented. It is understood that the State Council has issued 22 kinds of related documents to deploy and promote the innovation and Entrepreneurship. Innovation driven more and more become the national destiny and future. Among them, the innovative and entrepreneurial mode based on "Internet + " had become the new engine for the development of society and science and technology.

Under the background of national deployment of innovative national strategy, college students as the high quality human resources with most dynamic and creative of the whole country is the major force under the pattern of "great innovation", among them, electronic commerce specialized graduate student is more obvious advantage in the "Internet + " mode of innovation and entrepreneurship. However, colleges and universities as the first resources of talent and the first productivity of science and technology should focus on how to put effort into training the innovative and entrepreneurial talents under the electronic commerce "Internet +" mode, is a urgent problem to be researched.

At present, the proportion of college students' entrepreneurship is still very small, the road of college students' innovation and entrepreneurship walked is very difficult. Cultivating "Internet +" innovative and entrepreneurial talents, first is to help to ease college students employment pressure, transform the employment pressure into entrepreneurial drive; second is to improve college students' comprehensive qualities, competitive consciousness and survival ability, combine professional knowledge with business practice; third is to cultivate the spirit of having the courage to the exploration and innovation, improve college students' innovation spirit and innovation ability. 


\section{The current situation and main problems of innovative and entrepreneurial electronic commerce talent cultivation}

At present, the target location, training scheme, curriculum setting, teaching methods and guarantee system of electronic commerce specialized talents cultivation is not conducive to the cultivation of innovative and entrepreneurial talents.

(1) The location of innovation and entrepreneurship in the training goal is not clear

Electronic commerce specialty is a new specialty which is set up with the development of information science and technology to a certain stage, is in the exploration stage of the theory and practice. At the same time, the electronic commerce specialty is a multidisciplinary interdisciplinary specialty, covers the computer technology, management, economics and marketing, the partial emphasis of all schools in the electronic (computer technology) or the business (management, economics, marketing) is not the same.

There are many colleges and universities deal with the training goals and location of application issues, adaptability issues, personalization issues and comprehensive issues on electronic commerce talent cultivation, but completely ignore the innovative problems, even don't promote the innovation and entrepreneurship to a new strategic height. No innovation and entrepreneurship education in cultivation process, the trained graduates are not only lack of innovative and entrepreneurial ideas, but also don't have the ability of innovation and entrepreneurship, thus the graduate students who want to start a business but have no way to start, or blind entrepreneurship may also eventually encounter the risk of failure.

(2) The teaching mode of innovation and entrepreneurship curriculum system is not mature

Because e-commerce is an interdisciplinary specialty, at present, most colleges and universities when offer courses just simply put the information technology, economics, management and marketing together according to a certain proportion, is lack of knowledge system. Colleges and universities in the implementation of innovative and entrepreneurial education started quite late, still in the stage of exploration and research. Many colleges and universities because of no reference standard, entrepreneurship courses are very few, general 1-3 courses, and as the form of public elective course or second course, even some is only in the form of a lecture. Thus it can be seen that innovation and entrepreneurship was not attracted enough attention.

However, in the entrepreneurship course which has been set up, generally is talking in generalities for innovation and entrepreneurship cases in all industries, do not offer professional entrepreneurship courses for electronic commerce "Internet + " innovation mode, do not build a bridge between the professional knowledge of e-commerce and the innovation and entrepreneurship, to let the students apply their knowledge, thus can't achieve the leap from professional theoretical study to innovation and entrepreneurship practice.

(3) Lack of innovative and entrepreneurial faculty

"Internet +" innovation model talent cultivation, the key is whether the university itself has innovative and entrepreneurial faculty. According to the study found that many e-commerce specialty teachers of domestic colleges and universities basically are not graduated from the e-commerce specialty, most of them transformed from related specialty of computer or administration. Even though they have specialty background of e-commerce, due to the characteristic of specialty era, most of them are directly into teaching in colleges and universities after graduation, they are no experience of enterprise e-commerce construction and management, Internet innovation and entrepreneurship, thus still reflects the disadvantages of traditional education: attach importance to knowledge, neglect ability; attach importance to teacher, neglect students; attach importance to books, neglect practice; attach importance to class, neglect extracurricular; attach importance to inheritance, neglect innovation; attach importance to commonness, neglect personality. Obviously, the case teaching source of innovation and entrepreneurship can only be the book or network, it's not good to the cultivation of students' innovative practice ability.

(4) The teaching link of innovation and entrepreneurship practical is not in place 
Electronic commerce specialty is a specialty with strong practicality, so in the process of cultivating innovative talents of electronic commerce specialty, the practice is especially important. At present, most colleges and universities established the training rooms and experimental teaching system to meet the teaching needs, some also claimed that established several external training practice base, but most stayed in the demonstration stage, students only through the "look" or "simulate" to learn some practical process, but not have actually doing "practice", and external training practice base is worthy of the name, joint cultivation between colleges and enterprises is difficult to implement.

\section{Several suggestions on the talent cultivation of innovative and entrepreneurial e-commerce specialty}

(1) Perfect the innovation and entrepreneurship education curriculum system, organically integrate the professional education and innovation and entrepreneurship education

Universities should according to the location of talent cultivation and the goals and requirements of innovation and entrepreneurship education, to promote the organic integration of professional education and innovation and entrepreneurship education, to adjust the professional curriculum design, to excavate and enrich the innovation and entrepreneurship education resources of all kinds of professional course, to strengthen the innovation and entrepreneurship education in the process of imparting professional knowledge. Develop and offer the required courses and elective courses on the aspects of research methods, the forefront of the discipline, entrepreneurship basis, employment, entrepreneurship guidance and so on for all students, bring into credit management, construct the innovation and entrepreneurship education specialized courses of progressive, organic convergence, scientific and rational. Each universities should attach great importance to the information construction of innovation and entrepreneurship education quality courses, put efforts to launch online open courses, such as MOOC, micro-course, video public course and so on, set up the institution of learning authentication and credit authentication for online open course, organize the discipline leaders and enterprise talents, to write the innovation and entrepreneurship education key textbook with scientificity, advancement and applicability.

(2) Scientifically make talent cultivation plan, promote the talent cultivation and the economic and social development

Professional course knowledge modules need to be more explicit, such as know education curriculum, uniformly guided and set up by the national ministry of education, each schools according to the specialty to set up discipline foundation courses and professional courses, however, through the investigation and study, the teaching plan of most colleges and universities has curriculum rationality problems: such as the logic sequence is reversed, the proportion of theory practice is not scientific, the nature of the curriculum is not divided improperly, discipline foundation and the professional course is fuzzy and so on.

When making the teaching plans, should aim at cultivation direction to define the significance and status of each course set up, according to the requirement of the talent cultivation to set 1-2pcs of professional direction to make a plan. At the same time, it should also pay special attention to their own faculty and teaching conditions, the faculty is easy to solve, but there is no teaching conditions, even though some courses opened, but also can't achieve the training target. In addition, it also need to consider the logical consistency of the course and the equilibrium of each semester.

(3) Highlight the practical teaching link, cultivate students' application ability

The specialty must pay attention to the cultivation of students' practical application ability, continuously increase the investment, gradually improve the experimental teaching conditions, to set up a corresponding professional laboratory, virtual simulation laboratory, entrepreneurship laboratory and training center, to open innovative entrepreneurial resources to all students online, to arrange the senior professional titles teachers and the "double teacher type" teachers who have rich practical teaching experience to be responsible for the experimental course teaching, to effectively guarantee the teaching quality of experimental course, to invite senior e-commerce enterprise technical personnel to school to open seminar, to widen students' view. Establish the good 
cooperation relations with famous e-commerce enterprises and at the same time also should explore to establish new mechanism of cooperative training and cooperative education between school and school, school and research base, school and research laboratory, to establish a stable external practice bases, to employ enterprise excellent technicians as practice base teaching and guidance work, to organize students to the enterprise to attend project practice, professional practice and post-practice, organically combine the classroom teaching and extracurricular practice, to build a good platform of the professional practice for students.

(4) Strengthen innovation and entrepreneurship education, promote students' employment ability

The specialty must integrate the innovation and entrepreneurship education into the professional talent training scheme, carry out the indeed feasible talent cultivation mode, add innovation and entrepreneurship courses, establish entrepreneurial training platform, organize innovation and entrepreneurship related lectures, cultivate students' innovative spirit, entrepreneurial consciousness and entrepreneurial ability. Actively guide students to take an active part in all kinds of discipline competition, can hold professional skills competition activities in the school every year, and let students participate in some national subject competition activities, and then supplemented by the school training of bringing in enterprise faculty and projects which carried out during weekend, after nearly two years of try and exploration, has achieved initial results. The students' professional consciousness is obviously enhanced, personal professional development direction positioning is more accurate.

In a word, colleges and universities shoulder the important responsibility of talent cultivation, the measure to cultivate the innovative and entrepreneurial e-commerce specialty talent can't simply imitate and follow the prescribed order, need according to the requirement of national talent cultivation quality, to research and develop the characteristics of e-commerce venture curriculum system which truly adapt various colleges and universities education, then can cultivate high-quality talents with innovative thinking and entrepreneurial ability.

\section{References}

[1] Research on cultivation mode of e-commerce talent in applied colleges and universities undergraduate, Zhiliang Xing, Xibo Wen, Ce Zhang. Education and career. 2013.

[2] Analysis on the problems existing in the cultivation of innovative and entrepreneurial talents for electronic commerce specialty in Chinese Universities, Mingzhen Zhan. Enterprise herald. 2015.

[3] Thinking on the cultivation of innovative and entrepreneurial talents in Higher Vocational Education under the Internet Environment. Ping Fu, Aiping Xie. Electronic commerce. 2015.

[4] Research on the e-commerce entrepreneurship education in applied undergraduate course colleges and universities students. Rong Xie. Economic and technological cooperation information. 2014.

[5] 2016 Construction and practice of innovative and entrepreneurial talents cultivation course in applied Undergraduate e-commerce. Yang Liu. China science and technology investment. 2016. 